\title{
KAJIAN KELAYAKAN INVESTASI PADA RUKO MIRAI TRADE CENTER DI KABUPATEN BOYOLALI
}

\author{
Gigih Widiyanto $^{1)}$, Sugiyarto ${ }^{2)}$, Sunarmasto ${ }^{3)}$ \\ 1)Mahasiswa Fakultas Teknik, Prodi Teknik Sipil, Universitas Sebelas Maret \\ 2,3)Pengajar Fakultas Teknik, Prodi Teknik Sipil, Universitas Sebelas Maret \\ Jl. Ir. Sutami 36A, Kentingan, Surakarta 57126; Telp. (0271) 634524, Fax 662118 \\ Email : gigihwidi@gmail.com
}

\begin{abstract}
The investment business has begun to spread in several cities in Indonesia, the most popular of which is the property investment business. Businesses deserve to be increasingly seen by the community. The business is always increasing every year. Investment in the construction of an integrated shophouse is a wise choice as a solution to the needs of society in this modern era. In the process of building a shop house, it must be able to fulfill a feasibility study for investment both financially and in accordance with applicable regulations. The purpose of this research is to examine the feasibility analysis of investment in the Mirai Trade Center shop building project in terms of financial aspects which consist of Net Present V alue (NPV), Internal Rate of Return (IRR), Benefit Cost Ratio (BCR) which is then tested. At the level of sensitivity, it is expected that it can be seen how the parameters of the impact of investments that have previously been able to change the cause of certain circumstances and conditions during the investment period Based on the results of the calculation of investment analysis, where the investment period has been determined for 2 years, the minimum selling price of the shop unit with type 90 / 47.5 is Rp. 272,095,370.00, Net Present V alue (NPV) of Rp. 1,279,074,625.64 (NPV>0), the Internal Rate of Return (IRR) of 55.23\% (IRR> MARR), the Benefit Cost Ratio (BCR) is 1.1537 then, the results of the sensitivity analysis is known as the investment value of the Mirai Trade Center shop houses, therefore it can be said that it is not feasible to increase the cost of investment by $25.34 \%$, the decrease in the unit rate is over $27 \%$, the decrease in the selling price level is over $15.93 \%$, the increase in the interest rate is $30.9 \%$ greater.
\end{abstract}

Keywords: Minimum selling price, Investment, Investment feasibility, Shophouse

\begin{abstract}
Abstrak
Bisnis investasi sudah mulai menyebar di beberapa kota di Indonesia, yang paling marak adalah bisnis investasi properti. Bisnis propert semakin hari semakin dillirik kalangan masyarakat. Yang disebabkan karena bisnis tersebut selalu meningkat tiap tahunnya. Investasi pembangunan ruko yang terintegrasi merupakan salah satu pilihan yang bijak sebagai salah satu solusi akan kebutuhan masyarakat di era modern ini. Pembangunan ruko dalam prosesnya harus dapat memenuhi sebuah studi kelayakan investasi baik secara finansial maupun dapat sesuai peraturan yang berlaku. Tujuan yang dilakukan pada penelitian ini yaitu mengkaji analisis kelayakan investasi pada proyek pembangunan ruko Mirai Trade Center ditinjau dari aspek finansial yang terdriri dari Net Present Value (NPV), Internal Rate of Return (IRR), Benefit Cost Ratio (BCR) yang selanjutnya dilakukan pengujian pada tingkat sensitivitasnya yang diharapkan dapat diketahui bagaimana dampak parameter investasi yang sebelumnya sudah ditetapkan boleh berubah dikarenakan adanya factor situasi dan kondisi tertentu selama umur investasi. Berdasarkan dari hasil perhitungan analisa investasi yang dimana masa investasi telah ditetapkan selama 2 tahun diperoleh harga jual minimum unit ruko dengan tipe 90/47,5 yaitu Rp. 272.095.370.00, Net Present Value (NPV) sebesar Rp. 1.279.074.625.64 (NPV>0), Internal Rate of Return (IRR) sebesar 55,23\% (IRR > MARR), Benefit Cost Ratio (BCR) diperoleh sebesar 1,1537 kemudian untuk hasil analisa sensitivitas diketahui nilai investasi ruko Mirai Trade Center dapat disebut tidak layak apabila biaya kenaikan investasi lebih besar 25,34\%, penurunan tingkat unit terjual lebih besar $27 \%$, turunnya tingkat harga jual lebih besar 15,93\%, naiknya tingkat suku bunga lebih besar 30,9\%.
\end{abstract}

Kata Kunci : Harga jual minimum, Investasi, Kelayakan investasi, Ruko

\section{PENDAHULUAN}

Bisnis investasi sudah mulai menyebar di beberapa kota di Indonesia, yang paling marak adalah bisnis investasi properti. Bisnis propert semakin hari semakin dillirik kalangan masyarakat. Yang disebabkan karena bisnis tersebut selalu meningkat tiap tahunnya. Investasi pembangunan ruko yang terintegrasi merupakan salah satu pilihan yang bijak sebagai salah satu solusi akan kebutuhan masyarakat di era modern ini. Pembangunan ruko dalam prosesnya harus dapat memenuhi sebuah studi kelayakan investasi baik secara finansial maupun dapat sesuai peraturan yang berlaku. Tujuan yang dilakukan pada penelitian ini yaitu mengkaji analisis kelayakan investasi pada proyek pembangunan ruko Mirai Trade Center ditinjau dari aspek finansial yang terdriri dari Net Present V alue (NPV), Internal Rate of Return (IRR), Benefit Cost Ratio (BCR) yang selanjutnya dilakukan pengujian pada tingkat sensitivitasnya yang diharapkan dapat diketahui bagaimana dampak parameter investasi yang sebelumnya sudah ditetapkan boleh berubah dikarenakan adanya factor situasi dan kondisi tertentu selama umur investasi. 


\section{METODE}

Pada penelitian ini metode yang digunakan adalah analisis deskriptif kuantitatif. Deskriptif kuantitatif berarti pemaparan masalah yang ada pada saat ini disertai dengan hitungan, sedangkan analisis berarti menggunakan fakta atau informasi yang telah tersedia kemudian informasi tersebut disusun, dijelaskan, dan dianalisis. Penelitian ini diawali dengan pengumpulan data kemudian menganalisis data tersebut sehingga menghasilkan evaluasi proyek yang dibutuhkan.

\section{Lokasi Penelitian}

Penelitian ini dilakukan dengan mengambil kasus tentang proyek pembangunan ruko Mirai Trade Center di Kabupaten Boyolai, data yang diambil pada penelitian ini yaitu bulan Oktober-Desember 2019.

\section{Analisis Kelayakan Investasi}

Kriteria penilaian analisis kelayakan investasi menggunakan Net Present V alue, Internal Rate of Return, Benefit Cost Ratio, dan Analisis Sensitivitas.

\section{Net Present Value (NPV)}

Net Present V alue merupakan nilai bersih saat ini pada suatu investasi, kriteria NPV didasarkan atas konsep pendiskontoan seluruh arus kas investasi yang diukur pada nilai sekarang.

$$
\begin{aligned}
& N P V=P W B-P W C \ldots \ldots \ldots \ldots \ldots \ldots \ldots \ldots \ldots \ldots \ldots \ldots \ldots \ldots \ldots \ldots . .[1]
\end{aligned}
$$

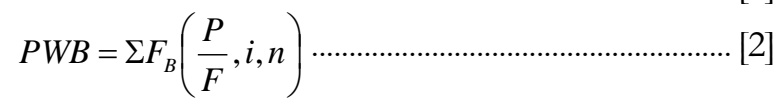

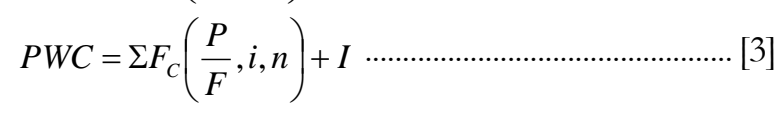

Keterangan :

$$
\begin{array}{ll}
\mathrm{I} & =\text { Investasi } \\
\mathrm{F}_{\mathrm{B}} & =\text { Future Benefit } \\
\mathrm{F}_{\mathrm{C}} & =\text { Future Cost } \\
\mathrm{PWB} & =\text { Present Worth of Benefit (nilai sekarang pendapatan) } \\
\mathrm{PWC} & =\text { Present } \text { Worth of Cost (nilai sekarang biaya) } \\
\mathrm{i} & =\text { Interest (bunga) } \\
\mathrm{n} & =\text { Periode }
\end{array}
$$

\section{Internal Rate of Return (IRR)}

IRR merupakan besarnya tingkat suka bunga menjadikan antara biaya pengeluaran dan biaya pendapatan nilainya sama.

$$
\begin{aligned}
& I R R=i_{1}+\frac{N P V_{1}}{N P V_{1}-N P V_{2}} \times\left(i_{2}-i_{1}\right) \\
& \text { Dimana : } i_{1}=\text { tingkat discount rate } N P V_{1} \\
& i_{2} \quad=\text { tingkat discount rate } N P V_{2} \\
& N P V_{1}=\text { net present value } 1 \\
& N P V_{2}=\text { net present value } 2
\end{aligned}
$$

\section{Benefit Cost Rasio (BCR)}

Metode benefit cast ratio (BCR) merupakan salah satu jenis kriteria yang biasanya digunakan dalam mengkaji kelayakan suatu proyek investasi..

$$
B C R=\frac{P W B}{P W C}
$$

\section{Analisa Sensitivitas}

Analisis sensitivitas dibutuhkan dalam rangka mengetahui sejauh mana dampak parameter-parameter investasi yang telah diterapkan sebelumnya boleh berubah karena adanya faktor situasi dan kondisi selama umur investasi, sehingga perubahan tersebut hasilnya akan berpengaruh secara signifikan pada keputusan yang telah diambil. 


\section{HASIL DAN PEMBAHASAN}

Proyek ruko Mirai Trade Center dibangun di atas lahan seluas $3.092 \mathrm{~m}^{2}$. Lokasi proyek ini terletak di Desa Kemiri, Kecamatan Mojosongo, Kabupaten Boyolali. Proyek ruko ini terdiri dari 27 unit tipe 90/47. dengan luas tanah 47,5 $\mathrm{m}^{2}$ dan luas bangunan $90 \mathrm{~m}^{2}$. Pengembangan proyek pertokoan ini direncanakan selama 2 tahun masa konstruksi. Dengan tingkat suku bunga pinjaman ditetapkan sebesar 14\% per tahun.

\section{Biaya Investasi}

Analisis biaya investasi pada ruko Mirai Trade Center dikeluarkan pada pengembangan proyek pertokoan yaitu meliputi dari biaya pematangan lahan atau Harga Pokok Pengembangan Tanah (HPPT) dan biaya pembangunan rumah atau Harga Pokok Pengembangan Bangunan (HPPB).

\section{Harga Pokok Pengembangan Tanah (HPPT)}

Biaya Perolehan Tanah

Biaya yang harus dikeluarkan untuk mendapatkan lahan tanah pada proyek Ruko Mirai Trade Center adalah sebesar Rp. 1.464.000.000,00

\section{Legalitas dan Perizinan}

Biaya yang harus dikeluarkan untuk membuat desain awal dan perijinan didasarkan peraturan yang berlaku di Kabupaten Boyolai yaitu sebesar Rp 194.686.000,00

\section{Biaya Pematangan Lahan}

Besarnya biaya pematangan lahan pada proyek ini meliputi bebarapa bagian yaitu pengurugan tanah, pembuatan dinding penahan tanah, dan pengerasan tanah jalan perumahan sebesar Rp 315.762.700,00

\section{Biaya Pematangan Lahan}

Besarnya biaya pematangan lahan pada proyek ini meliputi bebarapa bagian yaitu pengurugan tanah, pembuatan dinding penahan tanah, dan pengerasan tanah jalan perumahan sebesar Rp 315.762.700,00

\section{Biaya Lain-lain}

Pelaksanaan pekerjaan yang lainnya untuk mendukung kelancaran dalam pembangunan proyek perumahan memerlukan dana sebesar Rp 37.400.000,00

Hasil dari perhitungan dalam pengolahan lahan proyek ruko Mirai Trade Center seluas $2.092 \mathrm{~m}^{2}$ tersebut membutuhkan total biaya sebesar Rp 2.458.034.980,00

\section{Harga Pokok Pengembangan Bangunan (HPPB) \\ Biaya Pemasaran}

Biaya pemasaran merupakan dana yang digunakan untuk melakukan pemasran selama masa investasi ruko Mirai Trade Center. Biaya pemasaran pada umumnya terdiri dari biaya promis atau fee marketing. Jumlah biaya yang dibutuhkan selama pemasaran yaitu sekitar Rp. 178.500.000,00

\section{Biaya Kantor}

Dalam pelaksanaan proyek ruko Mirai Trade Center diperlukan sebuah asset kantor untuk kegiatan operasional proyek dan pemasaran ruko Mirai Trade Center. Oleh sebab itu diperlukan kegiatan pengadaan kantor beserta inventarisnya yang membutuhkan biaya sebesar Rp 127.000.000,00

\section{Gaji Karyawan}

Gaji karyawan pada proyek ruko didapatkan dengan pendekatan terhadap upah minimum kabupaten pada kota tersebut. Untuk pengeloaan gaji dilaksabakan secara flat selama 2 tahun beserta tambahan bonus. Untuk itu diperlukan biaya sebesar Rp.314.000.000,00

\section{Biaya Fasilitas}

Fasilitas ruko yang didapatkan oleh konsumen yaitu batas kaveling, biaya pemasangan air, biaya pasang listrik, dan Pemisahan IMB. Biaya fasilitas untuk rumah yang dibangun yaitu Rp 314.000.000,00 
Biaya yang harus dikeluarkan untuk proses pembuatan desain arsitektur dan sipil sebesar Rp. 5000.000,00

\section{Biaya Pelaksanaan Konstruksi}

Biaya Konstruksi bangunan ruko pada ruko Mirai Trade Center dengan harga satuan bangunan per meter persegi Rp 1.700.000,00 untuk tipe 90/47,5. Sehingga, perhitungan total biaya pembangunan proyek ruko adalah $=$ jumlah rumah $\times$ luas bangunan $\mathrm{x}$ harga satuan bangunan per meter persegi $=27$ unit $\times 90 \mathrm{~m} 2 \times \mathrm{Rp} 1.700 .000,00=$ Rp4.131.000.000,00

\section{Biaya Pelaksanaan Konstruksi}

Biaya Konstruksi bangunan ruko pada ruko Mirai Trade Center dengan harga satuan bangunan per meter persegi Rp 1.700.000,00 untuk tipe 90/47,5. Sehingga, perhitungan total biaya pembangunan proyek ruko adalah $=$ jumlah rumah $\times$ luas bangunan $\times$ harga satuan bangunan per meter persegi $=27$ unit $\times 90 \mathrm{~m} 2 \times \mathrm{Rp} 1.700 .000,00=$ Rp4.131.000.000,00

\section{Perhitungan Harga Jual Minimum Unit Ruko}

Harga minimum disini bertujuan untuk mengetahui dan mengendalikan dari risiko kerugian. Untuk penetapan harga jual minimum ruko ini supaya dapat mengetahui keuntungan yang didperoleh sesuai yang diharapkan. Harga jual minimum tiap unit ruko Mirai Trade Center diperoleh ketika jumlah pengeluaran sama dengan jumlah pendapatan.

\section{Harga Minimum Tanah}

Harga jual minimum tanah diperoleh dengan cara yaitu besar biaya tanah dibagi dengan total luas kaveling tanah. Harga jual tanah per $\mathrm{m}^{2}=\mathrm{HPPT} /($ Luas Kaveling $)=(\mathrm{Rp} 2.463 .543 .980,00) /\left(1282,5 \mathrm{~m}^{2}\right)$

$$
=\operatorname{Rp} 1.920 .884,97
$$

\section{Harga Minimum Bangunan}

Harga jual minimum bangunan ruko Mirai Trade Center diperoleh dengan cara yaitu besar biaya konstruksi dibagi dengan total luas lantai bangunan unit ruko.

Harga jual bangunan per $\mathrm{m}^{2} \quad=\mathrm{HPPB} /($ Luas Total Bangunan $)=(\mathrm{Rp} 4.883 .540 .000,00) /\left(2.430 \mathrm{~m}^{2}\right)$

$$
=\operatorname{Rp} 2.009 .687,24
$$

\section{Perhitungan Harga Jual Minimum Tiap Unit Ruko}

Harga jual minimum ruko didapatkan dengan rumus :

Harga jual minimum = luas tanah $\mathrm{x}$ harga tanah per $\mathrm{m}^{2}+$ luas bangunan $\mathrm{x}$ harga bangunan per $\mathrm{m}^{2}$

Harga jual minimum $\quad=47,5 \mathrm{~m}^{2} \times \mathrm{Rp} 1.920 .884+45 \mathrm{~m}^{2} \times \mathrm{Rp} 2.009 .687=\mathrm{Rp} 272.113 .888,00$

\section{Arus Kas}

Arus kas merupakan tafsiran yang menggambarkan aliran kas masuk dan arus kas keluar yang terjadi pada saat investasi dimulai sampai berakhirnya masa investasi tersebut. Aliran kas masuk didapatkan dari hasil penjualan tiap unit ruko sedangkan untuk kas keluar yakni biaya yang dikeluarkan selama proses pembangunan ruko.

\begin{tabular}{|c|c|c|c|c|}
\hline No. & Uraian & Tahun Ke-0 & Tahun Ke-1 & Tahun Ke-2 \\
\hline \multicolumn{5}{|c|}{ Dana Masuk } \\
\hline \multirow{4}{*}{1} & Modal Awal & Rp 1.619.631.480,00 & & \\
\hline & Pinjaman & & Rp 1.700.000.000,00 & \\
\hline & Penjualan Rumah & & Rp 4.224.400.000,00 & Rp 5.441.600.000,00 \\
\hline & Total Dana Masuk & Rp 1.619.631.480,00 & $\operatorname{Rp} 5.924 .400 .000,00$ & Rp 5.441.600.000,00 \\
\hline \multicolumn{5}{|c|}{ Dana Keluar } \\
\hline \multirow{6}{*}{2} & Harga Pokok & Rp 1.619.631.480,00 & Rp $831.903 .500,00$ & $12.000 .000,00$ \\
\hline & $\begin{array}{l}\text { Pengembangan Tanah } \\
\text { Harga Pokok }\end{array}$ & & $\mathrm{Rp} 4.310 .065 .000,00$ & Rp $\quad 573.475 .000,00$ \\
\hline & Pengembangan Bangunan & & & \\
\hline & Pembayaran Pinjaman & & & Rp 1.700.000.000,00 \\
\hline & Bunga Pinjaman & & Rp $\quad 193.666 .667,00$ & $\begin{array}{ll}\mathrm{Rp} & 210.000 .000\end{array}$ \\
\hline & Total Dana Keluar & Rp 1.619.631.480,00 & Rp 5.335.635.166,67 & Rp 2.453.475.000,00 \\
\hline
\end{tabular}

Tabel 1. Arus kas tahunan 
Vol 8, No 3 (2020): September

\begin{tabular}{lllclll}
\hline \multicolumn{7}{l}{ Saldo } \\
\hline 3 & Saldo & $\mathrm{Rp}$ & - & $\mathrm{Rp}$ & $588.764 .833,00$ & $\mathrm{Rp} 3.576 .889 .833,00$ \\
\hline
\end{tabular}

Dengan asumsi unit ruko terjual pada tahun pertama sebanyak 15 unit ruko Sedangkan, Tahun kedua proyek terjual sebanyak 12 unit ruko.

\section{Penetapan Minimum Attractive Rate Of Return (MARR)}

MARR merupakan tingkat pengembalian modal yang diinginkan oleh suatu organisasi yang sedang melukakan investasi, MARR digambarkan dalam bentuk presentase. Pada umumnya diketahui berdasarkan rata-rata suku bunga deposito bank di Indonesia.Tingkat suku bunga deposito Bank di Indonesia dapat dilihat pada Tabel 2.

Tabel 2. Suku bunga deposito

\begin{tabular}{lc}
\hline NAMA BANK & SUKU BUNGA DEPOSITO \\
\hline BANK TABUNGAN NEGARA & $5,8 \%$ \\
BANK NEGARA INDONESIA & $5,3 \%$ \\
BANK CENTRAL ASIA & $4,6 \%$ \\
BANK MANDIRI & $4,5 \%$ \\
BANK RAKYAT INDONESIA & $5,6 \%$ \\
RATA-RATA BUNGA DEPOSITO & $5,16 \%$ \\
\hline
\end{tabular}

Sumber : www.bi.go.id 30 Desember 2019

Tingkat pengembalian modal sendiri $=$ safe rate + risiko $=5,16 \%+5,16 \%=10,32 \%$

MARR = (ratio equity $\mathrm{x}$ rate of return $)+($ ratio loan $\mathrm{x}$ rate of return $)$

$$
\begin{aligned}
& =(49 \% \times 10,32 \%)+(51 \% \times 14 \%) \\
& =12,20 \%
\end{aligned}
$$

\section{Net Present Value}

Berdasarkan proyeksi pengeluaran dan pendapatan pada aliran kas dengan bunga ( $($ ) sesuai MARR 12,20\% per tahun. Hasil perhitungan mendapatkan nilai PWB sebesar Rp 9.602.442.657,83 dan PWC sebesar Rp 8.323.813.652,66 . Setelah dilakukan dengan perhitungan dengan rumus No. 1 didapatkan nilai NPV Rp 1.278.629.005,17. Karena NPV $=$ Rp 1.278.629.005,17 > 0, maka investasi tersebut layak untuk dilakukan.

\section{Internal Rate of Return (IRR)}

Perhitungan nilai Net Present Value (NPV) pada tingkat laju pengembalian hasil intern yang berbeda-beda dengan menggunakan cara Trial and Error untuk mencari nilai pada saat NPV menunjukkan positif dan negatif. Tingkat bunga pada nilai NPV positif dan NPV negatif tersebut di interpolasi. Dari hasil perhitungan didapat nilai IRR sebesar 55,21\%. Jadi, nilai IRR > MARR maka investasi proyek Ruko Mirai Trade Center tersebut layak untuk dilakukan.

\section{Benefit-Cost Ratio}

Berdasarkan hasil proyeksi hitungan dari PWB dan PWC yang kemudian dilakukan analisis investasi mengggunakan metode BCR mengunakan rumus No. 4 yang menghasilkan nilai Benefit Cost Ratio (BCR) sebesar 1,1536. Karena nilai BCR $=1,1536>1$ maka proyek layak dikerjakan karena nilai pendapatan lebih besar dari nilai biaya yang dikeluarkan.

\section{Analisis Sensitivitas}

Analisis sensitivitas bertujuan untuk mengetahui sejauh mana dampak parameter yang sebelumnya telah ditetapkan diperbolehkan untuk berubah, pada penelitian ini ada beberapa parameter yang akan mengalami perubahan antara lain tingkat biaya investasi, tingkat suku bunga, tingkat harga jual dan tingkat unit terjual.

\section{Perubahan Biaya Investasi}

Pada analisis sensitivitas terhadap biaya investasi, perubahan dilakukan pada biaya investasi awal dengan menaikkan biaya investasi awal secara bertahap sampai nilai NPV negatif. 
Tabel 3.Hubungan biaya investasi dan NPV

\begin{tabular}{llllrr}
\hline \multicolumn{1}{c}{ Perubahan } & & \multicolumn{2}{c}{ Biaya Investasi Total } & NPV \\
\hline Biaya Investasi Awal & $0 \%$ & Rp & $5.726 .943 .500,00$ & Rp & $1.279 .074 .626,00$ \\
Biaya Investasi Naik & $10 \%$ & Rp & $6.299 .637 .850,00$ & Rp & $744.340 .419,00$ \\
Biaya Investasi Naik & $20 \%$ & Rp & $6.872 .332 .200,00$ & Rp & $269.606 .213,00$ \\
Biaya Investasi Naik NPV Mendekati 0 & $25,34 \%$ & Rp & $7.178 .236 .847,00$ & Rp & $2.437,00$ \\
Biaya Investasi Naik & $30 \%$ & Rp & $7.445 .026 .550,00$ & $-\mathrm{Rp}$ & $253.127 .992,00$ \\
\hline
\end{tabular}

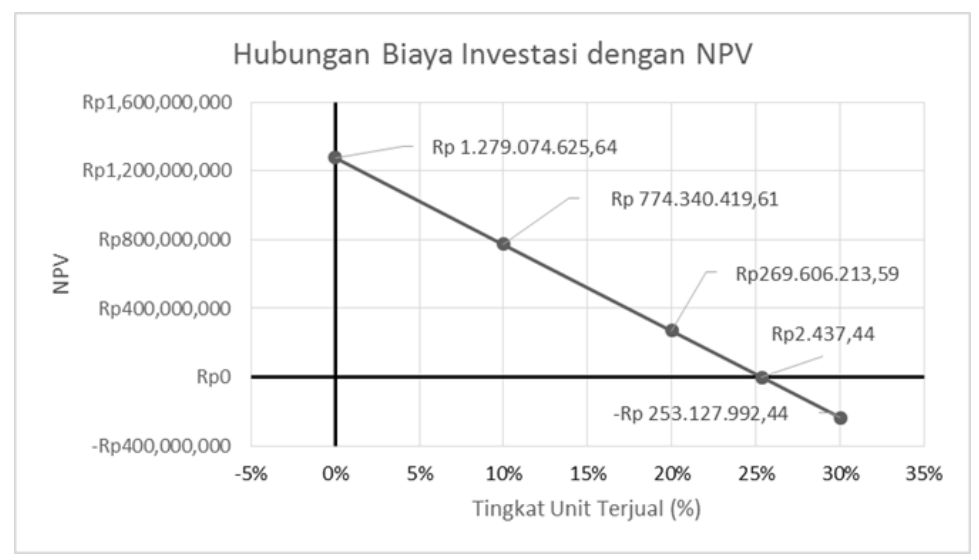

Gambar 1. Grafik hubungan biaya investasi terhadap NPV

Pada Gambar 1 didapatkan batas perubahan kenaikan biaya investasi pada ruko Mirai Trade Center adalah 25,34\% dari biaya investasi awal.

\section{Perubahan Tingkat Unit Terjual (Occupancy Rate)}

Pada analisis sensitivitas terhadap tingkat unit terjual, perubahan dilakukan pada tingkat unit terjual dengan menurunkan tingkat unit terjual secara bertahap sampai nilai NPV negatif.

Tabel 4. Hubungan tingkat penjualan unit rumah terjual dengan NPV

\begin{tabular}{llccc}
\hline \multicolumn{1}{c}{ Perubahan } & & Tingkat Unit Terjual & NPV \\
\hline Rencana Penjualan Ruko & $100 \%$ & 27 & Rp & $1.279 .074 .626,00$ \\
Rencana Ruko Berkurang 10\% & $90 \%$ & 24 & $\mathrm{Rp}$ & $763.943 .255,00$ \\
Rencana Ruko Berkurang 20\% & $80 \%$ & 22 & $\mathrm{Rp}$ & $396.062 .999,00$ \\
Rencana Ruko Berkurang NPV Mendekati 0 & $73 \%$ & 20 & $\mathrm{Rp}$ & $97.577 .728,00$ \\
Rencana Ruko Berkuran 30\% & $70 \%$ & 18 & $-\mathrm{Rp}$ & $193.968 .045,00$ \\
\hline
\end{tabular}

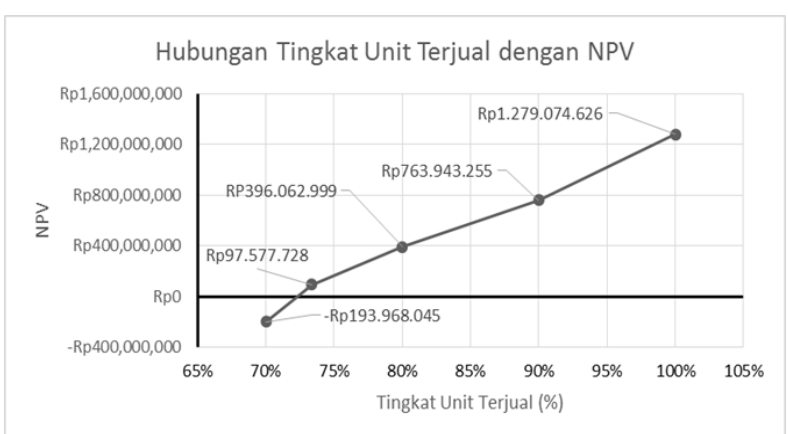

Gambar 2. Grafik hubungan perubahan tingkat unit terjual terhadap NPV

Pada Gambar 2 diperoleh batas perubahan penurunan penjualan unit ruko Mirai Trade Center sebesar -27\% atau 7 unit dari renacana penjualan awal. 


\section{Perubahan Harga Jual}

Pada analisis sensitivitas terhadap harga jual, perubahan dilakukan pada harga jual dengan menurunkan harga jual secara bertahap sampai nilai NPV negatif.

Tabel 5. Hubungan harga jual dengan NPV

\begin{tabular}{lllllr}
\hline \multicolumn{1}{c}{ Perubahan } & \multicolumn{2}{c}{ Harga Jual } & NPV \\
\hline Harga Jual Awal & $0 \%$ & $\mathrm{Rp}$ & $358.000 .000,00$ & $\mathrm{Rp}$ & $1.279 .074 .626,00$ \\
Harga Jual Menurun & $-10 \%$ & $\mathrm{Rp}$ & $322.200 .000,00$ & $\mathrm{Rp}$ & $479.272 .338,00$ \\
Harga Jual Menurun Mendekati NPV 0 & $-15,93 \%$ & $\mathrm{Rp}$ & $300.984 .202,00$ & $\mathrm{Rp}$ & 806,00 \\
Harga Jual Awal & $-20 \%$ & $\mathrm{Rp}$ & $286.400 .000,00$ & $-\mathrm{Rp}$ & $329.460 .968,00$ \\
\hline
\end{tabular}

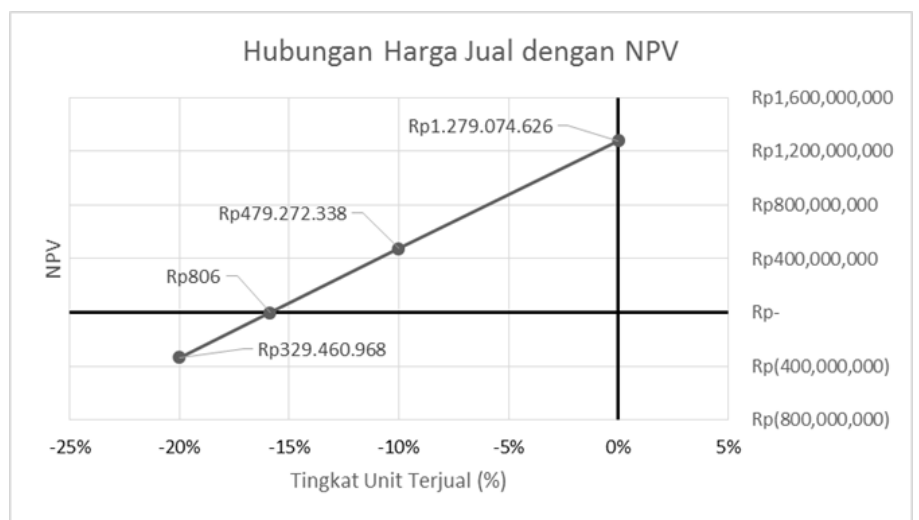

Gambar 3. Grafik hubungan perubahan harga jual terhadap NPV

Pada Gambar 3, diperoleh batas perubahan penurunan penjualan unit ruko Mirai Trade Center sebesar -15,93\% dari renacana harga jual awal.

\section{Perubahan Tingkat Suku Bunga}

Pada analisis sensitivitas terhadap tingkat suku bunga, perubahan dilakukan pada suku bunga awal dengan menaikkannya secara bertahap sampai nilai NPV negatif.

Tabel 6. Hubungan tingkat suku bunga dengan NPV

\begin{tabular}{llcrr}
\hline \multicolumn{1}{c}{ Perubahan } & & Suku Bunga & \multicolumn{1}{c}{ NPV } \\
\hline Suku Bunga Awal & $0 \%$ & $12,20 \%$ & Rp & $1.279 .074 .625,00$ \\
Suku Bunga Naik & $110 \%$ & $25,63 \%$ & Rp & $675.908 .349,00$ \\
Suku Bunga Naik & $220 \%$ & $39,05 \%$ & Rp & $261.164 .235,00$ \\
Suku Bunga Naik NPV Mendekati 0 & $309 \%$ & $49,92 \%$ & Rp & $1.167 .699,00$ \\
Suku Bunga Naik & $330 \%$ & $52,48 \%$ & -Rp & $52.537 .948,00$ \\
\hline
\end{tabular}

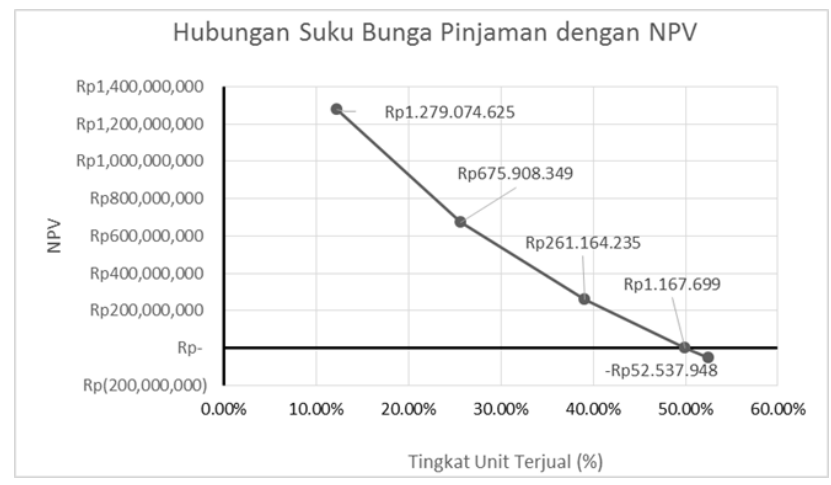

Gambar 4. Grafik hubungan perubahan suku bunga terhadap NPV 
Dari grafik hubungan perubahan tingkat suku bunga terhadap NPV, dapat diketahui batas perubahan kenaikan suku bunga pada proyek Ruko Mirai Trade Center yaitu sebesar 309\% dari suku bunga awal.

\section{SIMPULAN}

Berdasarkan analisa data dan pembahasan yang ditinjau dari aspek finansial, maka dapat diambil kesimpulan bahwa pembangunan proyek ruko Mirai Trade Center yakni layak dari segi aspek finansial. Dapat dilihat perolehan nilai sebagai berikut: Harga Jual Minumum tiap unit ruko yaitu 272.095.370,00 dengan tipe 90/47,5. Net Present Value (NPV) bernilai positif sebesar Rp.1.279.074.625,64 (NPV>0), Internal Rate of Return bernilai 55,23\% lebih besar daripada MARR yang bernilai 12,20 (IRR >MARR), dan BCR memiliki nilai rasio 1,1537 (BCR>1). Untuk hasil analisa sensitivitas diketahui investasi dapat dinyatakan tidak layak apabila didapat kenaikan biaya investasi lebih besar 25,34\% dari nilai biaya investasi awal, penurunan tingkat unit terjual lebih besar $27 \%$ atau 7 unit dari tingkat unit terjual awal, penurunan tingkat harga jual lebih besar 15,93\% dari harga jual awal yang ditentukan., kenaikan tingkat suku bunga lebih besar 30,9\% dari tingkat suku bunga awal.

\section{UCAPAN TERIMAKASIH}

Penyusun mengucapkan banyak terima kasih yang sebasar-sebearnya kepada Bapak Ir. Sugiyarto, M.T. dan Bapak Ir. Sunarmasto, M.T. selaku dosen pembimbing skripsi. Terima kasih atas semua waktu, bimbingan serta arahannya selama penyusunan skripsi sampai selesai. Terima kasih juga untuk semua pihak yang telah membantu penyelesaian penelitian ini baik secara langsung atau tidak langsung.

\section{REFERENSI}

Ready, Erwin, 2017, “Analisa Investasi Perumahan Kalianget Paradise di Kabupaten Sumenep Ditinjau dari Aspek Finansial”, Jurnal Teknik ITS. Vol. 6 No. 2. Institut Teknologi Sepuluh November. Surabaya.

Soeharto, Imam, 1997, "Manajemen Proyek : Dari Konsep Sampai Operasional”, Erlangga, Jakarta.

Kasmir, dan Jakfar, 2003, "Studi Kelayakan Bisnis Edisi Revisi”, Prenada Media, Jakarta.

M. Giatman, 2006, "Ekonomi Teknik”, PT Raja Grafindo Persada, Jakarta.

Robert, J. Kodoatie., 1995, “Analisis Ekonomi Teknik”, Andi, Yogyakarta.

Husnan, Suad., Suwarsono Muhammad., 2014, "Studi Kelayakan Proyek Edisi Ke-5”, UPP STIM YKPN. Yogyakarta.

Mariga, Yuda, 2018, "Perencanaan Investasi Pembangunan Perumahan dan Ruko "Amarta Residence" ditinjau dari Ekonomi dan Kebutuhan Pasar", Skripsi, Program Studi Teknik Sipil. Program Sarjana. Universitas Muhammadiyah Surakarta. 